MATEC Web of Conferences 22,04010 (2015)

DOI: $10.1051 /$ matecconf/ 20152204010

(C) Owned by the authors, published by EDP Sciences, 2015

\title{
Experiment Study on Permeability of Solidified Dianchi Peaty Soil
}

\author{
Mingshan Wang* \\ Faculty of Civil Engineering and Mechanics, Kunming University of Science \& Technology, Kunming, Yunnan, \\ China \\ Yunnan Branch of Jian Yan Foundation Engineering Co., Ltd., China Academy of Building, Kunming, Yunnan, \\ China \\ Yingjie Hou, Xingqi Dou, Zhihua Yu \& Jian Fu \\ Faculty of Civil Engineering and Mechanics, Kunming University of Science \& Technology, Kunming, Yunnan, \\ China
}

\begin{abstract}
In this paper, the permeability of Dianchi solidified peaty soil was studied by laboratory tests. The peaty soil was solidified by addicting cement, ardealite, lime, fly ash and their combination, and the coefficient of permeability under different curing stages were measured through the variable head method. Results showed that the coefficient of permeability of solidified peaty soil increased with the growth of the dosage of curing stagent and reduced with the growth of the stage. When the determined dosage in the deep mixing pile is used, it would be meet the permeability the need of the engineering.
\end{abstract}

Keywords: Dianchi; peaty soil; cement soil; coefficient of permeability; impermeability

\section{INTRODUCTION}

With the increase amount of high-rise buildings in Kunming, deeper and deeper foundation pit engineering will appear. The problem of water seepage has become the hidden trouble of the foundation pit excavation. In recent years, the application of cement deep mixing pile is well tested in practical engineering. Cement soil which controls building (structure) foundation seepage has been used in the civil, municipal, water conservancy, transportation and so on. Therefore, the permeability of solidified soil [1] has been the important topic in the research of civil engineering.

At present, many domestic and foreign scholars have studied the rule of the permeability of the solidified soil. Hong Guo et al. [2] discover the permeability characteristics of fly ash soil under different compaction degree and dosage of loess; Cheng Fu Chu et al. [3] illustrate that the permeability of undisturbed soil and compaction remolded soil can't reach $1 \times 10^{-7} \mathrm{~cm} / \mathrm{s}$, and put forward the best mixing cement ratio of the modified silty clay cushion is $12 \%$; Ze Ping Yang, Zheng Wei Gu et al. [4-7] also study the curing or improved soil permeability. These results indicate that the solidified soil has higher impermeability. However the study on the permeability of solidified peaty soil is rarely reported. The peaty soil is special soil consistsing of organic residues, humus and minerals. According to the specification [8], the soil organic matter content of peaty soil is between $10 \%$ and $60 \%$. Based on the statistics [9], the distribution of peaty soil is all over the world in 59 countries, with a total area of $4153000 \mathrm{~km}^{2}$. China peaty soil area is about 42000 *Corresponding author: yih53770@163.com $\mathrm{km}^{2}$. Peaty soil is widely distributed around Dianchi in Kunming. It does not belong to the common soil of six categories and has significant differences from silt and silty clay soil. Therefore, it is needed to give special reinforcement principles and methods for peaty soil in the practical engineering.

The permeability of Dianchi solidified peaty soil was studied by laboratory tests in this paper. Results showed that the coefficient of permeability of solidified peaty soil increased with the growth of the dosage of curing stagent and reduced with the stage growth. When the determined dosage in the deep mixing pile is used, it would be meet the permeability the need of the engineering.

\section{BASIC CHARACTERISTICS OF PEATY SOIL}

Soil samples were taken from an engineering site in Kunming, Yunnan province, and the site location and the process of sampling is briefly as follows:

It is located in the intersection of Guangfu road and Dianchi road in Kunming, in the central of basin, in the north of Dianchi, about $2 \mathrm{~km}$ away from the shore.

According to the survey, the field drilling reveals depth within the scope of soil layer from top to bottom: 1) layer of grain filling thickness $(1.0 \sim 6.0 \mathrm{~m}) ; 2)$ layer of organic soil thickness $(0.5 \sim 9.4 \mathrm{~m}) ; 3$ ) 1 layer of peaty soil thickness $(1.6 \sim 8.5 \mathrm{~m}) ; 4)$ silt layer thickness $(2.0 \sim 16.5 \mathrm{~m}) ; 5)$ layer containing organic clay (thickness $1.5 \sim 1.5 \mathrm{~m}$ ), etc. The test sample is layer of peaty soil, long-term in approximate saturation state, and belongs to typical limnetic facies soft soil. Use the geological drill core tube of the undis- 


\section{MATEC Web of Conferences}

turbed peaty soil samples, and take the samples in plastic bags, storage in the laboratory. Take peaty soil sample below Figure 1
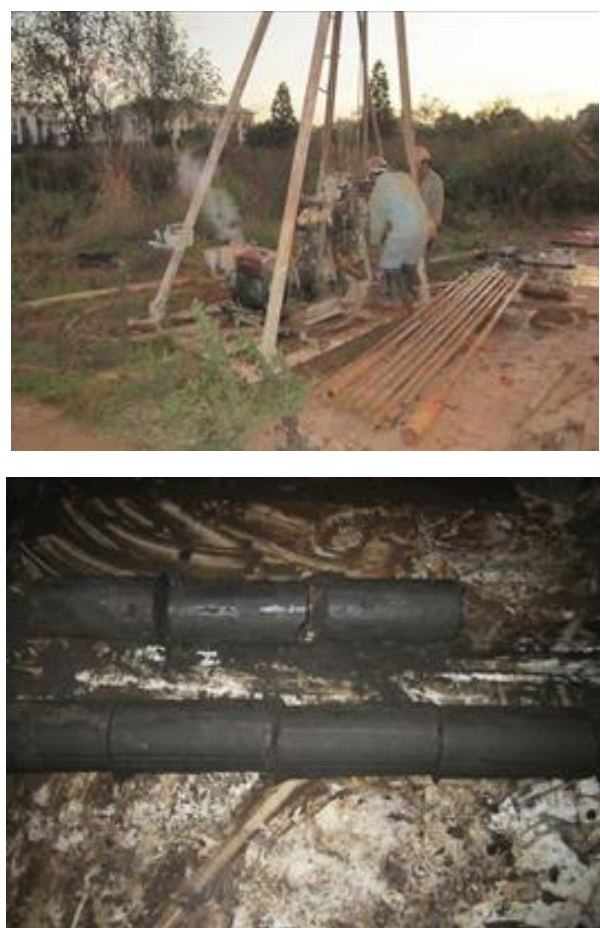

Figure 1. Sample of peaty soil

Physical and mechanical parameters of the samples are shown in Table 1, and the organic matter content is based on the calcination method of the highway soil test procedures [10].

\section{TEST PLAN}

\subsection{Sample preparation and maintenance}

Soil samples of this test used undisturbed soil and were taken from an engineering site in Kunming, Yunnan province. Calculate the material consumption on the basis of the test scheme of cement and admixture dosage. And then according to the water cement ratio, prepared solidifying slurry and weigh corresponding soil. Put the soil sample and solidified slurry into the basin, by artificial mixing, stirring time control in 5 10 minutes. Placed test sample in the test table then used the cutting ring of diameter $61.8 \mathrm{~mm}$ and height $40 \mathrm{~mm}$ to edge down and removed the redundant soil material, to level soil samples. The different ratios of cement soil had the corresponding label sample. Put the test sample in water. The cement soil curing times were 7 days, 14 days, and 28 days respectively.

\subsection{Test proportion}

By experimental study on different curing materials, the curing material was P S A32.5 Portland slag cement, ardealite, lime, fly ash and their combination. There were four test schemes. The first scheme was adding amount of P.S.A32.5 Portland slag cement in $20 \%, 25 \%, 30 \%, 35 \%$ respectively. The water cement ratio was 0.5 . The second scheme was the amount of cement $20 \%$, and the amounts of ardealite were $4 \%$, $7 \%, 10 \%, 13 \%$ respectively. The water cement ratio was 0.5 . The third scheme was the amount of cement $20 \%$, and the amounts of lime were $5 \%, 7 \%, 10 \%, 15 \%$ respectively. The water cement ratio was 0.5 . The last scheme was adding cement, lime, fly ash, namely the amount of cement $20 \%$, the amount of line $10 \%$, the amount of fly ash $4 \%, 8 \%, 12 \%, 16 \%$ respectively. The water cement ratio was 0.5 . When the cement soil curing time reached 7 days, 14 days, and 28 days, the cement soil was tested by variable head permeability. The results and analysis are as follow.

\section{ANALYSIS OF TEST RESULTS}

\subsection{Influence of cement content on the permeability}

The Figures 2 and 3 show that when the cement mixing ratio was $20 \%$, the coefficient of permeability of 7 day was $1.81 \times 10^{-7} \mathrm{~cm} / \mathrm{s}$. Compared to the coefficient of permeability undisturbed soil it reduced an order of magnitude. The coefficients of permeability of 14 days, 28 days were $1.4 \times 10^{-7} \mathrm{~cm} / \mathrm{s}, 1.17 \times 10^{-7} \mathrm{~cm} / \mathrm{s}$. At the stage of 28 days, the coefficient of permeability had a little change. When the content reached $25 \%$, the coefficients of permeability of 7 days, 14 days, and 28 days was $2.877 \times 10^{-7} \mathrm{~cm} / \mathrm{s}, \quad 2.084 \times 10^{-7} \mathrm{~cm} / \mathrm{s}$,

Table 1. Physical and mechanical parameters of the samples

\begin{tabular}{|c|c|c|c|c|c|c|c|c|c|c|c|c|c|}
\hline \multirow[b]{2}{*}{$\begin{array}{l}\text { Depth/ } \\
\mathrm{m}\end{array}$} & \multirow[b]{2}{*}{$\begin{array}{l}\text { Col- } \\
\text { our }\end{array}$} & \multirow{2}{*}{$\begin{array}{l}\text { Mois- } \\
\text { ture } \\
\text { content } \\
w / \%\end{array}$} & \multirow[b]{2}{*}{$\begin{array}{l}\text { Voi } \\
\mathrm{d} \\
l e_{0}\end{array}$} & \multirow[b]{2}{*}{$\begin{array}{l}\gamma \\
/(\mathrm{kN} / \mathrm{m} \\
\left.{ }^{3}\right)\end{array}$} & \multirow{2}{*}{$\begin{array}{l}\text { Spe- } \\
\text { cific } \\
\text { gravity } \\
G \mathrm{~s}\end{array}$} & \multirow{2}{*}{$\begin{array}{l}\text { Plas- } \\
\text { tic } \\
\text { limit } \\
w_{\mathrm{p}} / \%\end{array}$} & \multirow{2}{*}{$\begin{array}{l}\text { Liq- } \\
\text { uid } \\
\text { limit } \\
w_{1} / \%\end{array}$} & \multicolumn{3}{|c|}{ Grain group / \% } & \multirow{2}{*}{$\begin{array}{l}\text { The } \\
\text { or- } \\
\text { ganic } \\
\text { matter } \\
\text { con- } \\
\text { tent } \\
w_{\mathrm{u}} / \% \\
\end{array}$} & \multirow{2}{*}{$\begin{array}{l}\text { The } \\
\text { coefficient } \\
\text { of permea- } \\
\text { bility }\end{array}$} & \multirow[b]{2}{*}{$\mathrm{pH}$} \\
\hline & & & & & & & & $\begin{array}{l}\text { The } \\
\text { san } \\
\text { d }\end{array}$ & $\begin{array}{l}\text { Th } \\
\text { e } \\
\text { silt }\end{array}$ & $\begin{array}{l}\text { Th } \\
\text { e } \\
\text { cla } \\
\text { y }\end{array}$ & & & \\
\hline $6.2 \sim 6.4$ & black & 217 & $\begin{array}{l}4.1 \\
3\end{array}$ & 11.8 & 1.87 & 118.5 & 286.6 & $\begin{array}{l}44 . \\
4\end{array}$ & $\begin{array}{l}50 . \\
4\end{array}$ & 5.2 & 43.2 & $\begin{array}{l}2.99 \times \\
10^{-6}\end{array}$ & .6 \\
\hline $8.8 \sim 9.0$ & black & 229 & $\begin{array}{l}4.7 \\
6\end{array}$ & 11.3 & 1.99 & 135.2 & 385.6 & $\begin{array}{l}31 . \\
5\end{array}$ & $\begin{array}{l}62 . \\
0\end{array}$ & 6.5 & 51.0 & $\begin{array}{l}6.88 \times \\
10^{-6}\end{array}$ & ${ }^{6}$ \\
\hline
\end{tabular}


$1.902 \times 10^{-7} \mathrm{~cm} / \mathrm{s}$. Compared with $20 \%$ cement mixing ratio, all stages of the permeability coefficient were larger. Mixing ratio of $30 \%, 35 \%$, the coefficients of permeability of 7 days, 14 days, 28 days gradually reduced with time growth, but decreased slowly.

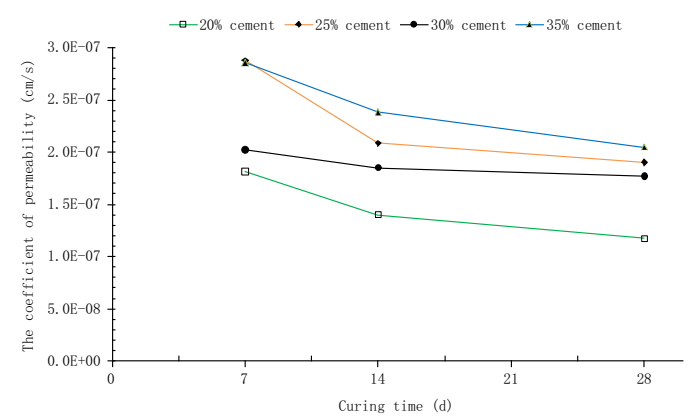

Figure 2. Effect of cement content on the permeability of solidified peat soil

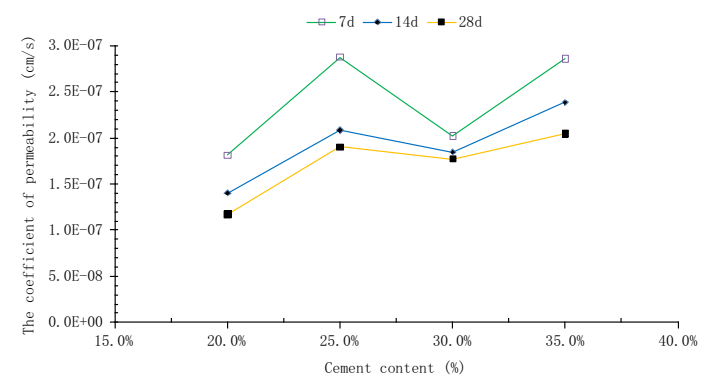

Figure 3. The variation curve of permeability of solidified peat soil with curing time

The main reason was that in the case of a single cement admixture and the influence of peat soil organic matter, the hydration reaction of cement was low, and it was less when it's generated by the hydration products. The porosity of the soil had not been completely blocked by the hydration products, which leaded to increase of the soil permeability coefficient with the increase of cement mortar and reduced the permeability of cement-treated soil properties gradually.

\subsection{Influence of ardealite content on the permeability}

The Figures 4 and 5 show the permeability of cement-treated soil reduced gradually with the dosage of ardealite. The coefficient of permeability fell along with the stage. When the dosage of ardealite was $4 \%$, the coefficient of permeability of 7 days $\sim 28$ days decreased from $1.54 \times 10^{-7} \mathrm{~cm} / \mathrm{s} \mathrm{cm} / \mathrm{s}$ to $1.098 \times 10^{-7} \mathrm{~cm} / \mathrm{s}$, and was reduced by $28.7 \%$, and the reduction is not obvious. The coefficient of permeability 28 days was the lowest. While the remaining three different dosages of solidified soil the coefficients of permeability in
7 days 28 days had the maximal reduction of $49.9 \%$ and minimal reduction of $4.4 \%$. Compared to the coefficient of permeability of remolded peaty soil, the coefficient of permeability is larger, so the effect of the combination of cement and ardealite was not obvious. The impermeability of the combination of cement and ardealite was not good.

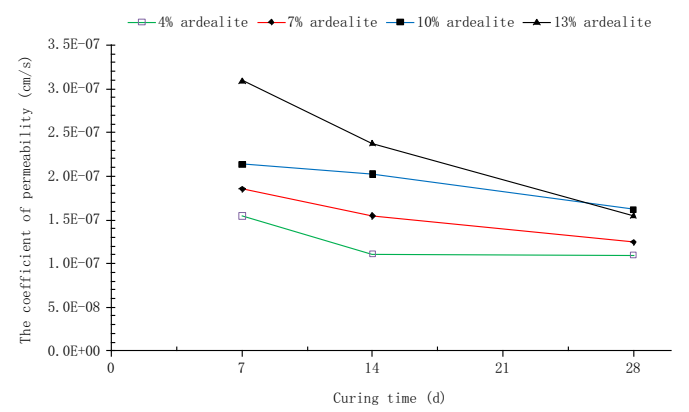

Figure 4. Effect of cement content on the permeability of solidified peat soil

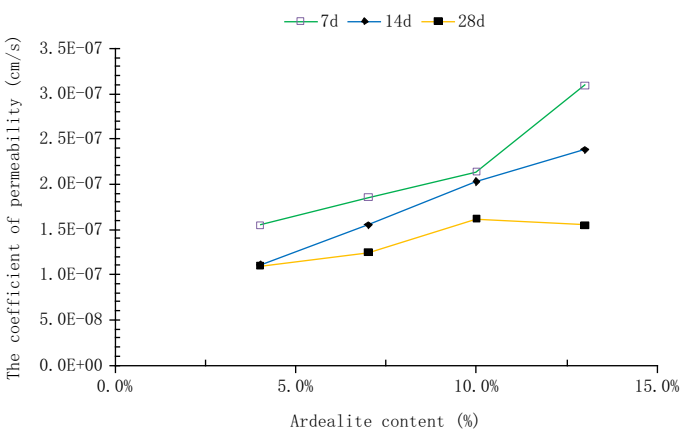

Figure 5. The variation curve of permeability of solidified peat soil with curing time

\subsection{Influence of lime content on the permeability}

The Figures 6 and 7 show the permeability of cement-treated soil was approximate under different stages. The permeability of cement-treated soil increased gradually with the increscent dosage of lime. The coefficient of permeability fell along with the stages. When the dosage of lime was $15 \%$, the coefficient of permeability of 7 days $\sim 28$ days decreased from $6.07 \times 10^{-7} \mathrm{~cm} / \mathrm{s} \mathrm{cm} / \mathrm{s}$ to $5.388 \times 10^{-7} \mathrm{~cm} / \mathrm{s}$. The permeability of cement-treated soil was the largest.

The main reason was that when only mixing lime cement slurry water also increased with the increase of lime. The mount of $\mathrm{Ca}(\mathrm{OH})_{2}$ would be increased in the slurry. And a large amount of $\mathrm{Ca}(\mathrm{OH})_{2}$ could inhibit the hydration reaction of cement, leading to the occurrence of chemical reaction which was not obvious. A lot of powder material of solidified soil was rushed out in the process of the normal seepage test. It may be calcium hydroxide which did not participate in 


\section{MATEC Web of Conferences}

the hydration reaction.

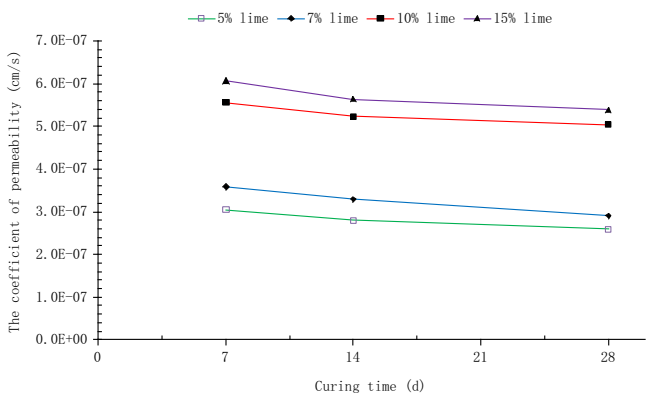

Figure 6. Effect of cement content on the permeability of solidified peat soil

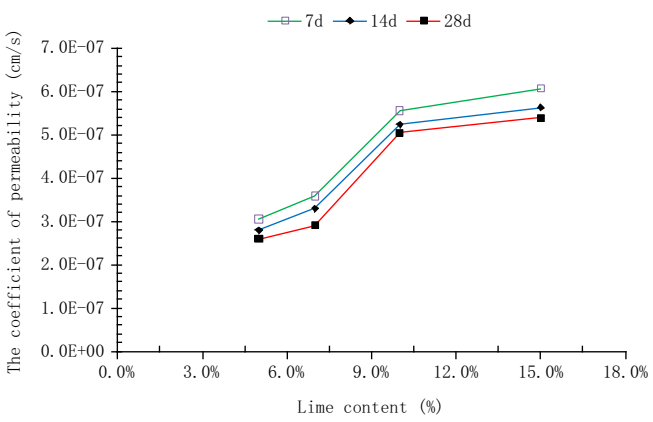

Figure 7. The variation curve of permeability of solidified peat soil with curing time

\subsection{Influence of fly ash content on the permeability}

The Figures 8 and 9 show the permeability of cement-treated soil reduced gradually with the dosage of fly ash. The coefficient of permeability fell faster along with the stage. When the dosage of fly ash was $4 \%$, the coefficient of permeability was high. When the dosage of fly ash was $8 \%$, the hydration products generation began to increase and the coefficient of permeability decreased along with the growth of the stage. The coefficient of permeability of solidified soil of 28 days was very low. Compared to the coefficient of permeability undisturbed soil it reduced two orders of magnitude. When the dosage of fly ash increased from $8 \%$ to $16 \%$, the coefficient of the dosage of fly ash will be larger, and the coefficient of permeability of solidified soil reducing along with stage would be more obvious. When the fly ash reached $12 \%$, the coefficients of permeability of 7 days, 14 days, 28 days were $6.596 \times 10^{-8} \mathrm{~cm} / \mathrm{s}, \quad 6.089 \times 10^{-7} \mathrm{~cm} / \mathrm{s}$, $4.718 \times 10^{-7} \mathrm{~cm} / \mathrm{s}$. The change of the coefficient of permeability was very small within 14 days. And the change of the coefficient of permeability was significant from 14 days to 28 day. Compared to the coefficient of permeability undisturbed soil it reduced two orders of magnitude and reduced by $53 \%$. When the dosage of fly ash was $16 \%$, the permeability of cement-treated soil was the lowest and the coefficient of permeability of 28 days was reduced by $0.66 \sim 0.96$ times compared other three kinds of fly ash soil.

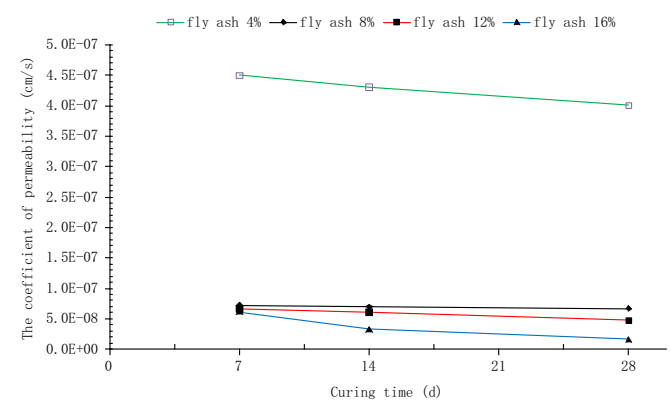

Figure 8. Effect of fly ash content on the permeability of solidified peat soil

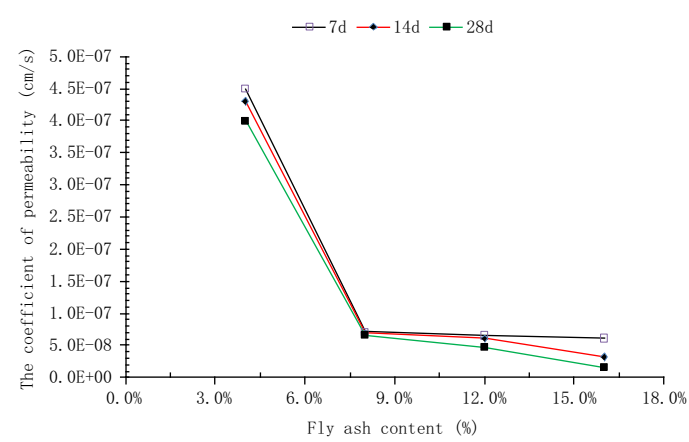

Figure 9. The variation curve of permeability of solidified peat soil with curing time

In cement, lime and fly ash soil, the permeability of cement-treated soil was affected by the structure of the soil. It generated a lot of hydrated calcium silicate and hydrated calcium aluminate crystals in the porosity of the soil. The formation of cement matrix filling the pores between the soil particles would effectively block the water channel. The amount of fly ash mixing decreased greater, the faster the coefficient of permeability decreased and the more obvious it changed with the stage in a certain range.

\section{CONCLUSIONS}

The coefficient of permeability of solidified peat soil increased with the growth of the dosage of curing agent and reduced with the stage growth. The impermeability of solidified peat soil would meet the engineering seepage resistance requirements.

In the test study of the permeability performance of addicting cement, ardealite, lime, fly ash and their combination, the impermeability of solidified soil single addicting ardealite was larger than the impermeability of solidified soil single addicting cement. The impermeability of solidified soil single addicting fly ash was the best. The impermeability of solidified 
soil single addicting lime was the worst. And most of the order of magnitude of the coefficient of permeability of solidified soil was in the range of $10^{-7} \mathrm{~cm} / \mathrm{s}$.

In the test study of the permeability performance of solidified peat soil, the best proportion of cement soil was that namely $20 \%$ dosage of cement, lime $10 \%$ dosage of lime, and the appropriate mix content of the fly ash range was $8 \% \sim 16 \%$.

\section{REFERENCES}

[1] Xiaonan Gong. 1997. New Technology of Foundation Treatment. Taiyuan: Shanxi Science and Technology Press.

[2] Hong Guo. 2009. Test research on considering regional difference of saturated loess triaxial permeability. China Rural Water Conservancy and Hydropower, 26(3): 39-44.

[3] Chengfu Chu, Xinghuai Huang, Qibo Tong. 2009. Test research of powder compaction engineering properties. Journal of Hefei University of Technology (Natural Science Edition), 32(3): 403-406.

[4] Zeping Yang. 2011. Test Research on Three Kinds of Improved Soil Permeability. Lanzhou: Lanzhou University of Technology.

[5] Zhengwei Gu, Bingnan Sun. 2003. Clay test research on undisturbed soil, remolded soil and solidified soil permeability. Journal of rock mechanics and engineering, 22(3): 505508

[6] Yonghong Miao, Shengzhong Wu, Yaosheng Zhang. 2000. Test research on deep mixing method change coarse sand permeability. Journal of Taiyuan University of Technology, 31 (2): 178-182.

[7] Suping Han, Shengzhong Wu. 2003. Test research on impervious slurry change of soil permeability. Journal of Taiyuan University of Technology, 34 (1).

[8] Industry standard of the People's Republic of China GB50021-2009 Geotechnical Engineering Specification [S]. Beijing: China building industry press, 2002.01.10

[9] Mesri G, Ajlouni M. 2007. Engineering properties of fibrous peats. Journal of Geotechnical and Geo-environmental Engineering, 133(7): 850-866.

[10] Research Institute of Highway Ministry of Transport. Test methods of soils for highway engineering (JTG E40-2007). Beijing: China Communication Press, 2007. 